\title{
Online Education during COVID-19 in Bangladesh: University Teachers' Perspective
}

\author{
Mimma Tabassum ${ }^{1}$, Seefat E Mannan ${ }^{2}$, Md Iftakhar Parvej ${ }^{1 *}$, Firoz Ahmed ${ }^{3}$
}

\author{
${ }^{1}$ Department of Statistics, Noakhali Science and Technology University, Noakhali, BANGLADESH \\ ${ }^{2}$ Department of Social Work, Noakhali Science and Technology University, Noakhali, BANGLADESH \\ ${ }^{3}$ Department of Microbiology, Noakhali Science and Technology University, Noakhali, BANGLADESH \\ *Corresponding Author: iftakhar.nstu@gmail.com
}

Citation: Tabassum, M., Mannan, S. E., Parvej, Md. I., Ahmed, F. (2021). Online Education during COVID-19 in Bangladesh: University Teachers' Perspective. Aquademia, 5(1), ep21005. https://doi.org/10.21601/aquademia/9611

\section{ARTICLE INFO}

Received: 10 Nov. 2020

Accepted: 20 Dec. 2020

\begin{abstract}
In Bangladesh like the other nations around the world educational sector is highly affected by COVID-19. During this lockdown teachers may help their students to minimize the educational gap. An online survey was conducted from 30 July to 24 September 2020 to collect the information from teacher of different public and private universities. Descriptive statistics was used to find their perceptions about online education, and problems faced related to e-learning. About $88.5 \%$ of the participants take online classes during the pandemic among them majority (91.3\%) of them were staying at home and continue their online educational support to the students. They may face some problem during the online classes and poor internet connection (69.31\%) and lack of logistic support (19.13\%) were the main problem they faced. Very few $(1.4 \%)$ of them think the process are not helping the students to overcome the educational gap. This study will helpful for government and the educational authority to find the overall scenario of online education during lockdown from teachers' point view.
\end{abstract}

Keywords: COVID-19, lockdown, online education, public and private university teachers, Bangladesh

\section{INTRODUCTION}

COVID-19, a highly infectious disease has changed the regular picture of the whole world. Having the severe possibility of spreading among individuals during close contact is causing millions of deaths (Mishra et al., 2020). This pandemic severely impacted the socio-economic and many other basic factors around the world and educational factor is no exception to that.

In March 2020, COVID-19 has resulted in academic closure in Bangladesh (Moralista \& Oducado, 2020). This closure of academic institutions severely impacted the majority of the student population and also other involved people of the education sector. Many countries all over the world have started the online education system and they are continuing with this process to minimize the gap (Rahman, 2020). Online education through social media is now the best possible alternative to face to face learning. Platforms like Facebook, Zoom, Google classroom, Google meet etc are some of the mediums through which academic institutions are trying to communicate with the students (Fami, 2020).

Online learning is not that easy for a country like ours. It is a big challenge not only for the learners but also for the teachers. Changes to the educational system including technical support, administrative planning, maintaining online schedule and data, all are very much new for the teachers. In this regard along with preparing lectures they must have proper skills and knowledge of using technical properties.

Government has taken some initiatives to help the educational institutions to conduct classes in this lockdown. But most of the rural and some underprivileged urban areas are at a disadvantage for continuing this process (Fami, 2020). Both teachers and students from such territories are facing distance issues, limited technical assistance, lack of internet access and financial insufficiency.

Distance learning has many benefits (Al-Husban, 2020; Seage \& Türegün, 2020) and limitations (Weinhandl et al., 2020). Many factors are considered as obstacles to e-learning (Gokdas \& Kayri, 2005). In a recent study in India found many positive and negative opinions about online education (Arora \& Srinivasan, 2020). There are many studies that show the conditions of students experiencing online education but comparatively fewer studies are conducted describing the circumstances of the teachers in this regard.

During COVID-19 lockdown how teachers help their students to minimize the educational gap, their perceptions about online education, and problems related to e-learning are the main aim of this study. 


\section{METHODS AND METERIALS}

This is an online survey-based study of the 353 private and public university teachers in Bangladesh. An online survey was conducted from 30 July to 24 September 2020 to collect the information by non-probability convenience sampling procedure. A well-structured questionnaire was designed which contained some demographic characteristics and information about online classes, their experience and challenges. Questionnaire link using ‘Google form' was sent to respondents through email and Facebook messenger. Prior to starting the survey, the aims, objectives and the confidentiality of given responses were clarified with participants. After reading, participants gave their consent to participate by clicking either "Yes" or "No." A total of 313 participants send complete information regarding the survey. Descriptive statistics were carried out to understand the distribution of study participants. Simple percentage distribution was estimated to assess the opinion on online classes, and problems related to study due to the lockdown. IBM SPSS Statistics 25.0. was used to conducted the statistical analysis.

\section{RESULT AND DISCUSSION}

\section{Demographic Characteristics of the Participants}

A total of 313 questionnaires out of 353 were returned. We had the responding rate of $88.7 \%$, which has been an acceptable rate. The demographic data of the participants are demonstrated in Table 1 . Of 313 participants, $49.8 \%$ were aged below 31 years, $48.9 \%$ were aged between $31-50$ years, and the rest were aged 51-65 years. Two of every five participants were female. Half of the respondents were resided urban areas, and very few $(10.2 \%)$ of the respondents were from rural areas. The majority of them were from public universities (81.5\%). Half of the students were from the Science academic background (56.2\%). One fourth of the teachers experienced more than 06 years in our study.

Educational Status of the Participants

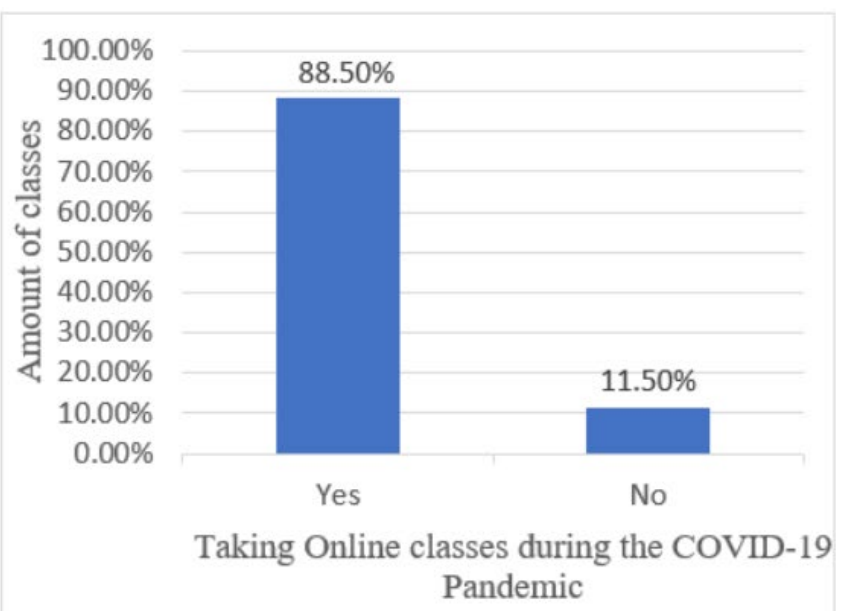

Table 1. Demographic characteristics of the participants (n313)

\begin{tabular}{lcc}
\hline Characteristics & Frequency & Percentages (\%) \\
\hline Age of the respondents & 156 & \\
\hline Below 31 & 113 & 39.8 \\
\hline $31-40$ & 40 & 12.8 \\
\hline $41-50$ & 4 & 1.3 \\
\hline $51-65$ & 124 & \\
\hline Gender & 189 & 39.6 \\
\hline Female & 60.4 \\
\hline Male & \\
\hline Current place of residence & 32 & 10.2 \\
\hline Rural & 123 \\
\hline Semi-Urban & 39.3 \\
\hline Urban & 158 & 50.5 \\
\hline Institutions & 18.5 \\
\hline Private University & 58 \\
\hline Public University & 255 & 81.5 \\
\hline Academic background & \\
\hline Science & 176 \\
\hline Arts & 57 \\
\hline Commerce & 56.2 \\
\hline Teaching Experience & 18.2 \\
\hline Below 02 years & 25.6 \\
\hline 02-05 years & \\
\hline 06-10 years & 125 \\
\hline Above 10 years & 109 \\
\hline & 52 & 39.9 \\
\hline & 27 & 16.6 \\
\hline
\end{tabular}

Figure 1 highlights the educational status of the participants. About $11.5 \%$ of the participants did not take online classes during the pandemic. Those who are taking their interactions with students for study purpose majority (91.3\%) of them were staying at home and continue their online educational.

\section{Perception about Online Classes}

Results given in Table 2 shows that the Respondents perception and experiences about online classes. Among them $53.1 \%$ were taking 02 to 05 online courses and around two of every five respondents spend more than 05 hours per week for online classes. Our study finds that $66.8 \%$ of the teachers experienced online classes first time during the COVID-19 pandemic and most $57.1 \%$ ) of them were developing their online teaching experience. Among them only $10 \%$

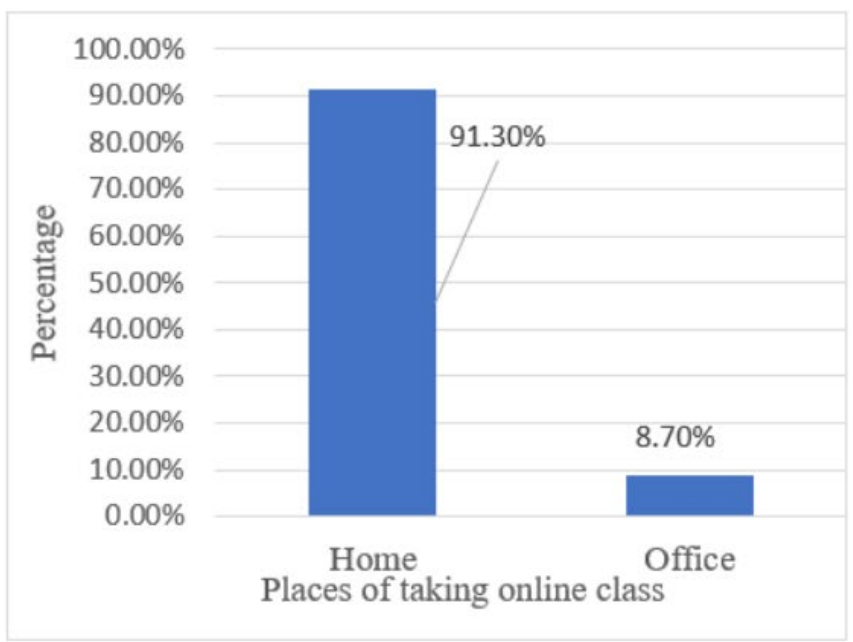

Figure 1. Taking online classes either home or office during the COVID-19 Pandemic 
Table 2. Perception and experiences about online classes (n277)

\begin{tabular}{|c|c|c|}
\hline Variables & Frequency & Percentages (\%) \\
\hline \multicolumn{3}{|c|}{ Numbers of online courses taken } \\
\hline Below 02 & 20 & 7.2 \\
\hline $02-05$ & 147 & 53.1 \\
\hline More than 05 & 110 & 39.7 \\
\hline \multicolumn{3}{|c|}{ Hours giving online classes per week } \\
\hline 01-02 hours & 73 & 26.4 \\
\hline 03-04 hours & 93 & 33.6 \\
\hline 05-06 hours & 63 & 22.7 \\
\hline Above 06 hours & 48 & 17.3 \\
\hline \multicolumn{3}{|l|}{ Online teaching experiences } \\
\hline Some/little & 53 & 19.1 \\
\hline Regular & 39 & 14.1 \\
\hline First Time & 185 & 66.8 \\
\hline \multicolumn{3}{|l|}{ Efficiency in online teaching } \\
\hline Efficient & 107 & 38.6 \\
\hline Not efficient & 12 & 4.3 \\
\hline Developing/learning & 158 & 57.1 \\
\hline \multicolumn{3}{|l|}{ Training taken for online classes } \\
\hline Peer training/workshops & 25 & 9.9 \\
\hline No training & 252 & 90.1 \\
\hline \multicolumn{3}{|l|}{ Gadgets for taking online classes } \\
\hline Laptop or Computers & 220 & 79.4 \\
\hline Tab & 16 & 5.8 \\
\hline Smartphone & 41 & 14.8 \\
\hline \multicolumn{3}{|c|}{ Internet connection for online classes } \\
\hline Broad Band & 129 & 46.6 \\
\hline Mobile Data & 148 & 53.4 \\
\hline
\end{tabular}

participants of our study taking training about online teaching. $79.4 \%$ of our teachers used laptop or computers for taking online classes and half of them were used mobile data to take their classes.

\section{Platform Uses and Problem Facing during Online Classes}

Figure 2 illustrate that, for e-lectures, respondents in study were using various platforms such as the Google classroom, Zoom app, Skype. Facebook room, Google meets (meetings) etc. the study revealed that most of the teachers (58.12\%) prefer the Zoom app for their e-lectures. Majority of the respondents in our study faced some problem during the online classes and poor internet connection (69.31\%) and lack

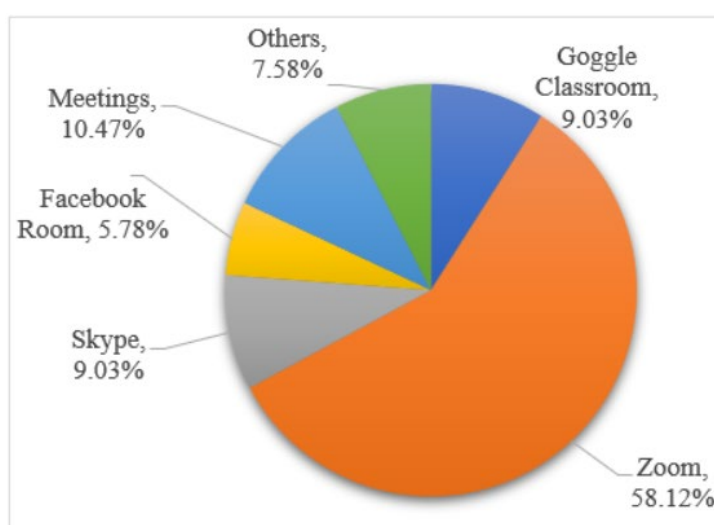

Figure 2. Parentage distribution of platform using in online classes

Table 3. Students participation and evaluation (n-277)

\begin{tabular}{lcc}
\hline Variables & Frequency & Percentages (\%) \\
\hline Attendance level of your students & & \\
\hline Below $40 \%$ & 44 & 15.9 \\
\hline 40 to $60 \%$ & 104 & 37.5 \\
\hline 60 to $80 \%$ & 97 & 35.0 \\
\hline Above $80 \%$ & 32 & 11.6 \\
\hline Response of the students & & \\
\hline Satisfying & 149 & 53.8 \\
\hline Not Satisfying & 128 & 46.2 \\
\hline Taking any online examinations & & \\
\hline Yes & 104 & 37.5 \\
\hline No & 149 & 53.8 \\
\hline May be & 24 & 8.7 \\
\hline
\end{tabular}

of logistic support (19.13\%) were the main problem they faced (Figure 3).

\section{Students Participation and Evaluation}

Among the study participants maximum teachers find $40 \%$ to $80 \%$ during their online classes and students respond rate was fifty-fifty they revealed. More than half of our participants did not take any online examination (Table 3).
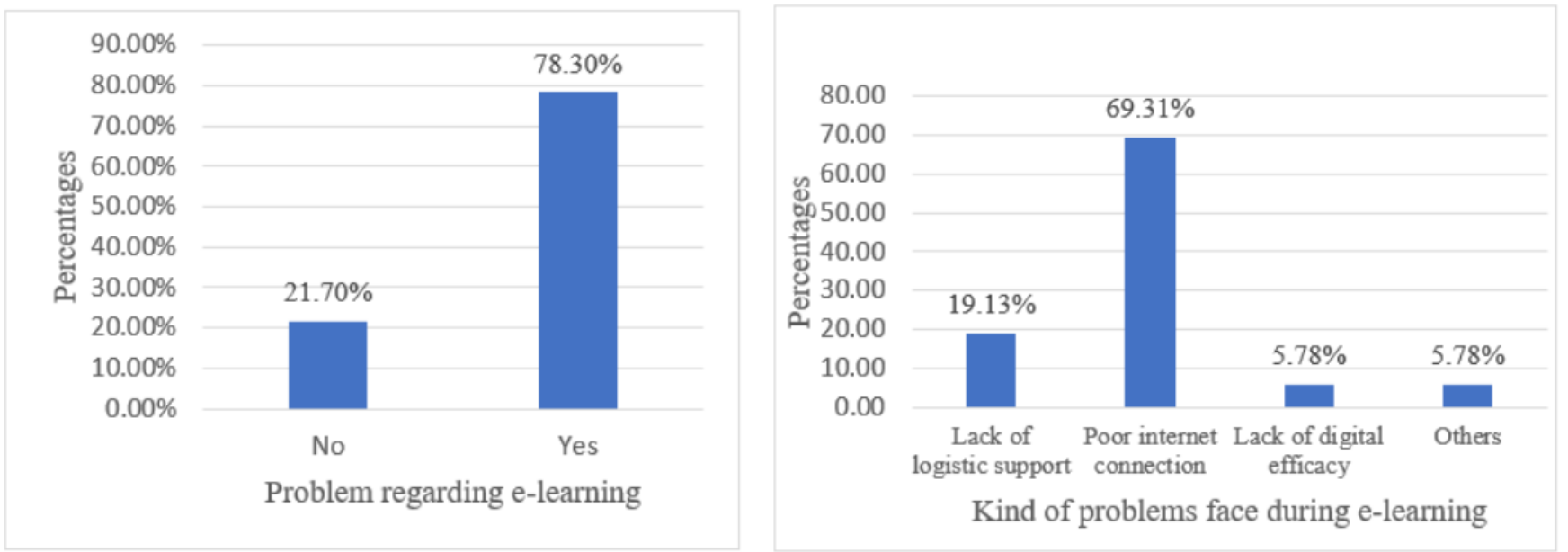

Figure 3. Problem facing during online classes 
Table 4. Students participation and evaluation (n-277)

\begin{tabular}{|c|c|c|}
\hline Variables & Frequency & Percentages (\%) \\
\hline \multicolumn{3}{|c|}{ Essential to continue the e-learning process } \\
\hline Yes & 221 & 79.8 \\
\hline No & 12 & 4.3 \\
\hline Not decided & 44 & 15.9 \\
\hline \multicolumn{3}{|c|}{$\begin{array}{l}\text { Online education is helping the students to overcome the } \\
\text { educational gap }\end{array}$} \\
\hline To a short extent & 108 & 39.0 \\
\hline To an average range & 116 & 41.9 \\
\hline To a large extent & 49 & 17.7 \\
\hline Not a bit & 4 & 1.4 \\
\hline \multicolumn{3}{|c|}{ Some subjects are difficult to be delivered through online } \\
\hline Yes & 273 & 98.6 \\
\hline No & 4 & 1.4 \\
\hline
\end{tabular}

Importance of E-learning Process during Lockdown

Table 4 shows that maximum (79.8\%) teachers in our study think that, it is essential to continue this e-learning process and very few (1.4\%) of them think the process are not helping the students to overcome the educational gap. They also added some of the subjects are very difficult to delivered through online.

Our study revealed that, majority of the teachers were continuing their e-learning process to help the students to minimize their study gaps. Poor internet connection be the main problem they faced during their class.

\section{CONCLUSION}

The academic activities have significantly disrupted and the students are so much frustrated to think about their academic future for this unexpected COVID-19 lockdown. Our study evaluated the teacher's perception about the online education of private and public universities in Bangladesh during this pandemic. Some of the teachers face little bit challenge in online teaching. Our study has revealed the overall scenario and the perceptions about online teaching in under graduation and post-graduation level. We think that it will be helpful for the government and institutional authorities to make an academic decision. By using this information, they can make a plan for the universities to continue the e-learning process during this pandemic.

\section{REFERENCES}

Al-Husban, N. A. (2020). Critical Thinking Skills in Asynchronous Discussion Forums: A Case Study. International Journal of Technology in Education, 3(2), 82-91. https://doi.org/10.46328/ijte.v3i2.22

Arora, A. K., \& Srinivasan, R. (2020). Impact of Pandemic COVID-19 on the Teaching-Learning Process: A Study of Higher Education Teachers. Prabandhan: Indian Journal of Management, 13(4), 43-56. https://doi.org/10.17010/pijom/ 2020/v13i4/151825

Fami, S. B. T. a. T. (2020). Is online education system suitable for Bangladesh? The Business Standard. Retrieved on 11 November 2020 from https://tbsnews.net/thoughts/ online-education-system-suitable-bangladesh-112546

Gokdas, I., \& Kayri, O. G. M. (2005). E-learning, the problems and solution recommends in terms of Turkey Situation.

Mishra, L., Gupta, T., \& Shree, A. (2020). Online teachinglearning in higher education during lockdown period of COVID-19 pandemic. International Journal of Educational Research Open, 100012. https://doi.org/10.1016/j.ijedro. 2020.100012

Moralista, R., \& Oducado, R. M. (2020). Faculty Perception toward Online Education in a State College in the Philippines during the Coronavirus Disease 19 (COVID-19) Pandemic. Universal Journal of Educational Research, 8(10), 4736-4742. https://doi.org/10.13189/ujer.2020.081044

Rahman, N. E. (2020). Online education during COVID-19: Prospects, challenges and way forward. The Independent. Retrieved on 11 November 2020 from http://www.theindependentbd.com/post/254623

Seage, S. J., \& Türegün, M. (2020). The Effects of Blended Learning on STEM Achievement of Elementary School Students. International Journal of Research in Education and Science, 6(1), 133-140. https://doi.org/10.46328/ ijres.v6i1.728

Weinhandl, R., Lavicza, Z., Hohenwarter, M., \& Schallert, S. (2020). Enhancing flipped mathematics education by utilising GeoGebra. International Journal of Education in Mathematics, Science and Technology, 8(1), 1-15. https://doi.org/10.46328/ijemst.v8i1.832 